\title{
Research on self-esteem levels of visually handicapped individuals who do and do not perform sports
}

\author{
İbrahim DALBUDAK ${ }^{1}$ Şıhmehmet YiĞiT² ${ }^{2}$ Fikret RAMAZANOĞLU ${ }^{3}$
}

${ }^{1}$ Atabey Vocational School Isparta, Süleyman Demirel University Turkey,

${ }^{2}$ Faculty of Sports Sciences, Sakarya University, Sakarya, Turkey

${ }^{3}$ Faculty of Sports Sciences, Sakarya University, Sakarya, Turkey

\section{Abstract}

The purpose of this study is to examine the self-esteem levels of visually handicapped individuals who do sports and do't do sports. There were 106 sportsmen and 94 persons with visual handicapped (200 in total) who participated in the research clubs in the province of Izmir. As the sub-problems, the relationship between the genders of participant who visually handicapped and not visually handicapped was investigated. The study consists of two parts. In the first part, the demographic characteristics of the participants were determined; in the second part Rosenberg Self Value scale consisting of 10 questions was used. Data were analyzed with SPSS 18.00 package program. T test, correlation analysis, descriptive statistics were applied to test hypotheses of the study. The research found that there is a significant difference between the self-esteem levels of individuals with and without visually handicapped sports $(P<0.05)$. No statistically significant difference was found between the self-esteem levels of the sportsmen and the sportswomen $(P>0,05)$. There was no significant difference in the self-esteem levels of visually handicapped individuals who played individual sports and team sports $(P>0,05)$. As a result, it has been seen that sports have a positive effect on self-esteem in visually handicapped individuals and they contribute and hold to life more meaningful.

\section{Key words: Visually Handicapped, Visually Handicapped Sportsman, Rosenberg Self- Esteem}

\section{Introduction}

Individuality is the attitudes that a person develops about himself as a result of social interactions with other people. In other words; it involves the answers of these questions: "What am I? What can I do? What are the things that are important for me? What do I want from life?". Thus individuality comes to a state of pattern related to the individual's features, abilities, value judgments, ambitions and ideas [6]. The most important factor which effects personality is individuality. Individuality consists of the views about our own personality and our own outlooks. In this respect, individuality can be defined as the private sight of personality. Thereby, individuality is a dynamic pattern of an individual's features, abilities, value judgments, ambitions and ideas. Individuality means to be conscious. Individuality is a spiritual and physical concept. Concept of individuality is to be conscious of one's own identity [1]. At various points in a human life, emotional and cognitive variables contribute diversely to the individual's concept of individuality. At the same time individuality, based on the feedback received from the environment, shows improvement with social interactions. We are emphasizing on evaluating the concept of individuality and especially on self-esteem [9]. Self-esteem is to be self-confidence as much as to respect himself, to value himself with all his aspects, to like himself, to approve, to be satisfied with himself and to find himself positive and worth to be loved. Shortly, self-esteem is an evaluation of an individual and its permanency. Such an evaluation is about how an individual reveals his abilities, to be adored and accepted in society, to accept and embrace his own physical features and to show his judgment about himself [11]. On the other hand an individual with low self-esteem has a low self-confidence, he easily gets desperate, shortly, he is more likely to develop negative psychiatric symptoms [7].

In its broadest sense, self-esteem means an individual who is proud of himself and feels valuable, diligent, effective and successful. It is a feeling which appears as a result of a complex self-judgment and evaluation. It is an approval that results in self-acceptance by evaluating himself [12].

People with high self-esteem behave differently from people with low self-esteem. Study results show that high self-esteem generally puts the individual into active and social relationships while low self-esteem causes an individual to feel under pressure and weak in society [12]. Several studies have put forward the 
benefits of physical activity on mental health and its usage as an assistance strategy in developing an individual's psychological functions. Concept of individuality, as an indicator of mental health and individual's psychological functions, has been one of the most investigated psychological concepts related to sports, physical activity and training according to its important role in an individual's daily life happiness, success in life's different dimensions and in interrelating effectively with people [1].

It was determined that training and physical fitness programs have potential for decreasing the individual's physical ability and self-acceptance. Folkins and Sime (1981) have determined that physical ability training decreases the concept of individuality. In such researches it was determined that training has a positive effect on the concept of individuality [13]. Disability is a situation or a function which is evaluated as significantly corrupted according to an individual's or a group's general standards. The term corresponds to individual functions that involve physical inability, sensory impairment, cognitive impairment, mental disorders, and various chronic disease types [3]. Visually handicapped is described as unrecoverable visual loss which affects one's educational success negatively. Enç's (1972) definition is as follows; even after all necessary and possible recoveries are made, people with maximal one out of ten normal visual efficiency are called visually handicapped [3].

IBSA has determined three classes in an international competition for partially or fully visually handicapped sportsmen. They are;

B1: is for those who are either not capable of sensing the light or capable of sensing the light but with weak recognition of the shape of objects in a given distance or located at horizontal direction at eye. B2: is for those who are capable of determining the shape of a hand; but having a 2/60 visual acuity or having less than 5 sight degree.

B3: is for those who have either more than $2 / 60$ or until $6 / 60$ visual acuity or for those with more than 5 , less than 20 sight degree [3].

It was not thought for many years that, like healthy people, for escaping physical and psychological regression in order to provide physical suitability for life conditions, advised sportive activities or sports can be practiced also on disabled people [3]. Sports has unlimited benefits for physical means. When compared with classical therapeutic exercises, a sport shows superiority in entertaining and connecting the patient with life. The primary goal in sports for handicapped people is to give them an opportunity to have a contact with the outer world. As sports physically and mentally enhances the human and arouses the feelings of trust, discipline, competition and friendship, it greatly decreases the possibilities of joining and being useful for society. In some sports branches like archery, billiards, table tennis and swimming, it could be seen that handicapped people can compete with normal people [3].

Sports also fulfills a very important function in integration that is targeted to be reached in private education by providing a possibility for handicapped people to come together with healthy and handicapped people. In such environment a handicapped individual develops a positive attitude for himself by observing other handicapped people, stimulates his creativity, his feelings of loneliness increases, his environment improves and catches a chance of a more meaningful life [3]. Our physical and mental features have an effect in developing the concept of individuality. A handicapped individual must first orient himself with his own disability. Especially when an insufficiency such as visual disability, which limits security and freedom, is in question, it must be considered that it can affect the development of selfesteem. A visually handicapped individual's attitude, feeling and understanding to his disability can make significant impacts on his personality and adaptation [6]. In the view of such information; the effect of sports in visually handicapped people who do and do not perform sports in developing self-esteem was investigated in this research. Such a research was needed to be done as previous researches about visually handicapped people are insufficient in our country. This research is thought to be useful for further researches in this field.

\section{Materials and Methods}

This section includes the model of the researcher, the group of the researchers, the data collection tool, analyzes, methods and techniques related to the solution of the data. 


\subsection{Research Model}

The research was based on quantitative research design. General screening model was applied in order to arrive at a general judgment about the universe, in which the whole universe or a sample taken from it was scanned.

\subsection{Research Sample}

There were 106 sportsmen and 94 persons with visual impairments (200 in total) who participated in the research clubs in the province of Izmir.

\subsection{Data Collection Tools}

A survey form (EK-1, EK-2) that is convenient with the information in the theoretical section of the research has been prepared. The survey has 2 sections. In the first section, demographic features (age, gender, educational status, weather performing sports or not, level of income, branch of sports) of the sportsmen are involved.

In the second section self-esteem scale (Rosenberg's Self Esteem Scale (RSES)) is involved which was developed by Rosenberg in 1965. It was used in many researches after the validity and reliability studies were made in U.S.A. Scale's standardization studies in Turkey, language adaptation, validity and reliability study was made by Çuhadıroğlu and the validity coefficient was found as $r=71$. By using a retest reliability method, the reliability coefficient was determined as $r=75$. In the research, among 12 subscales with 63 articles, only the first subscale was used for scaling the self-esteem. In the Self-Esteem Subscale, 10 regulated articles according to Guttman scale are involved. Each expression involves quartet Likert type options (very true, true, wrong, very wrong). Positive and negative loaded articles are arranged consecutively. Subjects are receive a score between 0 to 6 according to the scaling system. In the comparisons made with quantitative measurements, subjects with high self-esteem have (0-1), middle have (2-4), low have (5-6) scores [8].

\subsection{Analysis of Data}

In the research primarily the descriptive statistics' data related to the variables, later the test's data and correlation analysis's data were presented in tables in the order of data's statistical analysis and evaluation. Evaluation of the data was carried out with SPSS 18.00.

\section{Results}

In order to find out the relation between their self-esteem, 106 visually handicapped sportsmen and 94 visually handicapped non-sports performers were involved in the research. Thus, the survey was carried out on 200 people in total. As sub-problems according to the gender of the visually handicapped individuals, the relation between sports performers and non-performers and the relation between individual and group sports were investigated. In order to measure the subjects 'self-esteem Rosenberg Self-Esteem Scale was used. Information about the purpose and importance of the study and the survey was given to the subjects, who were involved in the research, before presenting them the survey. The surveys were send and answers were received via Hotmail in computer environment and the surveys were recollected again by Hotmail. Rosenberg Self-Esteem Scale was carried out on visually handicapped individuals.

Table 1 shows the evaluation of self-esteem degrees between visually handicapped sportsmen and visually handicapped individuals who do not perform sports.

Table 1. The Relation Between Sports Performers And Non-Performers

\begin{tabular}{llllll}
\hline $\begin{array}{l}\text { The Parametres } \\
\text { Measured }\end{array}$ & $\begin{array}{l}\text { Sports Performers } \\
\mathrm{N}=106\end{array}$ & $\mathrm{~T}$ & $\mathrm{P}$ & $\begin{array}{l}\text { Non-Sports } \\
\text { Performers } \\
\mathrm{N}=94\end{array}$ & Total Group \\
\hline BS & $3,62 \pm 0,89$ & $-24,89$ & 0,00 & $0,87 \pm 0,63$ & $2,16 \pm 1,58$
\end{tabular}

* $\mathrm{P}<0,05$

According to Table $1(P<0,05)$, the difference between the self-esteem of sports performers and nonperformers was evaluated. The self-esteem degree of the sports performers is higher than those who do not perform sports. So, significant difference was determined statistically $(p=0,00)$. 
Table 2 shows the evaluation of the self-esteem degrees of male visually handicapped sportsmen and male visually handicapped non-sports performers.

Table 2. The Relation Between Male Sportsmen And Male Non-Sports Performers

\begin{tabular}{llllll}
\hline $\begin{array}{l}\text { The Parametres } \\
\text { Measured }\end{array}$ & $\begin{array}{l}\text { Male Sportsmen } \\
\mathrm{N}=56\end{array}$ & $\mathrm{~T}$ & $\mathrm{P}$ & $\begin{array}{l}\text { Male Non-Sports } \\
\text { Performers } \mathrm{N}=50\end{array}$ & Total Group \\
\hline BS & $3,64 \pm 0,81$ & $-18,19$ & 0,00 & $0,88 \pm 0,75$ & $2,17 \pm 1,59$
\end{tabular}

* $\mathrm{P}<0,05$

According to Table $2(P<0,05)$, the self-esteem levels of males who do sports are higher than the males who don't do sports. So, a significant different was found statistically $(p=0,00)$.

Table 3 shows the evaluation of the self-esteem degrees of female visually handicapped sportsmen and female visually handicapped non-sports performers.

Table 3. The Relation Between Female Sportsmen And Female Non-Sports Performers

\begin{tabular}{llllll}
$\begin{array}{l}\text { The Parametres } \\
\text { Measured }\end{array}$ & $\begin{array}{l}\text { Female Sportsmen } \\
\mathrm{N}=50\end{array}$ & $\mathrm{~T}$ & $\begin{array}{l}\text { Female } \\
\text { Sports Performers } \\
\mathrm{N}=44\end{array}$ & Non- Total Group \\
\hline BS & $3,60 \pm 0,99$ & $-16,86$ & 0,00 & $0,86 \pm 0,46$ & $2,15 \pm 1,57$
\end{tabular}

* $\mathrm{P}<0,05$

According to Table $3(P<0,05)$, the self-esteem levels of females who do sports are higher than the females who don't do sports. So, a significant different was found statistically $(p=0,00)$.

Table 4 shows the evaluation of self-esteem levels between visually handicapped male sportsmen and visually handicapped female sportsmen.

Table 4. The Relation Between Male And Female Sportsmen

\begin{tabular}{llllll}
\hline $\begin{array}{l}\text { The Parametres } \\
\text { Measured }\end{array}$ & $\begin{array}{c}\text { Male Sportsmen } \\
\mathrm{N}=56\end{array}$ & $\mathrm{~T}$ & $\mathrm{P}$ & $\begin{array}{l}\text { Female } \\
\text { Sportsmen } \\
\mathrm{N}=50\end{array}$ & Total Group \\
\hline BS & $0,88 \pm 0,75$ & $-0,14$ & 0,892 & $0,86 \pm 0,46$ & $0,87 \pm 0,63$
\end{tabular}

* $\mathrm{P}>0,05$

According to Table $4(P>0,05)$, there is no self-esteem difference between male and female sportsmen. So, there is no significant difference statistically. $(p=0,892>0,05)$.

Table 5 shows the evaluation of self-esteem levels between male and female non-sports performers.

Table 5. The Relation Between Male And Female Non-Sports Performers

\begin{tabular}{llllll}
\hline $\begin{array}{l}\text { The Parametres } \\
\text { Measured }\end{array}$ & $\begin{array}{l}\text { Male Non-Sports } \\
\text { Performers }\end{array}$ & $\mathrm{T}$ & Female & Non- Total Group \\
& $\mathrm{N}=50$ & & Sports & \\
& & & & $\begin{array}{c}\text { Performers } \\
\mathrm{N}=44\end{array}$ & \\
\hline BS & $3,64 \pm 0,81$ & $-0,152$ & 0,880 & $3,60 \pm 0,99$ & $3,62 \pm 0,90$ \\
\hline
\end{tabular}

* $\mathrm{P}>0,05$

According to Table $5(P>0,05)$, there is no difference in self-esteem level between male and female nonsports performers. So, there is no significant difference statistically. $(p=0,880>0,05)$.

Table 6 shows the evaluation of self-esteem levels of male visually handicapped non-sports performers and female visually handicapped sportsmen. 
Table 6. The Relation Between Female Sportsmen And Male Non-Sports Performers

\begin{tabular}{llllll}
\hline $\begin{array}{l}\text { The Parametres } \\
\text { Measured }\end{array}$ & $\begin{array}{l}\text { Male } \\
\text { Performers } \\
\mathrm{N}=50\end{array}$ & $\mathrm{P}$ & $\begin{array}{l}\text { Female } \\
\text { Sportsmen } \\
\mathrm{N}=50\end{array}$ & Total Group \\
\hline BS & $0,86 \pm 0,46$ & $-21,06$ & 0,00 & $3,64 \pm 0,81$ & $2,25 \pm 1,54$ \\
\hline
\end{tabular}

* $\mathrm{P}<0,05$

According to Table $6(\mathrm{P}<0,05)$, the self-esteem level of female sportsmen is higher than male non-sports performers self-esteem level. So, there is a significant difference statistically. $(p=0,00)$.

Table 7 shows the evaluation of self-esteem levels between male visually handicapped sportsmen and female visually handicapped non-sports performers.

Table 7. The Relation Between Male Sportsmen And Female Non-Sports Performers

\begin{tabular}{|c|c|c|c|c|c|}
\hline $\begin{array}{l}\text { The Parametres } \\
\text { Measured }\end{array}$ & $\begin{array}{l}\text { Male Sportsmen } \\
\quad \mathrm{N}=56\end{array}$ & $\mathrm{~T}$ & $P$ & $\begin{array}{l}\text { Female Non- } \\
\text { Sports Performers } \\
\mathrm{N}=44\end{array}$ & Total Group \\
\hline BS & $3,60 \pm 0,99$ & $-15,18$ & 0,00 & $0,88 \pm 0,75$ & $2,08 \pm 1,61$ \\
\hline
\end{tabular}

$* \mathrm{P}<0,05$

According to Table $7(P<0,05)$, the self-esteem level of male sportsmen is higher than the female non-sports performers. So, there is a significant difference statistically. $(p=0,00)$

Table 8 shows the evaluation of self-esteem levels between visually handicapped sportsmen who play in group teams and whom play individually.

Table 8. The Relation Between Individual And Team Sports

\begin{tabular}{llllll}
\hline $\begin{array}{l}\text { The Parametres } \\
\text { Measured }\end{array}$ & $\begin{array}{c}\text { Team Sports } \\
\mathrm{N}=61\end{array}$ & $\mathrm{~T}$ & $\mathrm{P}$ & $\begin{array}{l}\text { Individual } \\
\text { Sports } \\
\mathrm{N}=45\end{array}$ & Total Group \\
\hline BS & $0,96 \pm 0,72$ & 1,95 & 0,054 & $0,74 \pm 0,45$ & $0,86 \pm 0,63$
\end{tabular}

* $\mathrm{P}>0,05$

According to Table $8(P>0,05)$, there is no difference in self-esteem levels between the ones who play either individual or team sports. So, there is no significant difference statistically. $(p=0,054>0,05)$.

\section{Discussion and Conclusion}

The primary aim of this research is to determine the sports' role in effecting the self-esteem levels of visually handicapped people. The secondary aim of this research is to determine whether there is a different or not between demographic features and self-esteem levels. This study was carried out in İzmir, on 106 sportsmen, who plays in school and various clubs and 94 non-sports performers; thus, 200 visually handicapped individuals in total. There were 106 male and 94 female participants.

A significant difference was found in the self-esteem levels between visually handicapped sportsmen and visually handicapped non-sports performers. It can be said that there is a positive relation between doing sports and self-esteem. $(P<0,05)$. Ebru Gün, has made a study in 2006 and found out that there is a significant difference in self-esteem scores between those who do and do not perform sports. Valley (2006), has determined that training has a positive effect on self-esteem [6]. This approves our research. It has been thought that performing sports provides a positive benefit in self-esteem.

A significant difference was found in the self-esteem levels between visually handicapped male sportsmen and male non-sports performers $(P<0,05)$. It can be said that there is a positive relation between performing sports and self-esteem. In Özgeylani's (1996) research, where he compares the concept of individualism among high-school sportsmen and non-sports performers, he has determined that sportsmen 
have a higher concept of individualism [6]. It is thought in this study that a sport provides a positive benefit in decreasing self-esteem.

A significant difference was found in self-esteem levels between visually handicapped female sportsmen and visually handicapped female non-sports performers $(P<0,05)$. The concept of individualism is about self-perception and understanding. Self-esteem is an emotional side of individualism and rises from approving the concept of individualism at the end of evaluating one self, and results in adoring himself. An individual does not need to be highly qualified to like himself and respect his own individuality. In its broadest sense, self-esteem means an individual who is proud of himself and feels valuable, diligent, effective and successful. Providing a benefit in developing self-esteem could be possible together with physical education and sportive activities in individuals' physical development, and bringing in the feeling of self-reliance and sufficiency [8]. The difference in self-esteem levels of female sportsmen and female nonsports performers supports our study.

No significant difference could be found in self-esteem levels between male sportsmen and male nonsports performers $(P>0,05)$. In the study of K.A. Erman, A. Şahan, S. Can, no difference was observed in selfesteem parameter between male and female sportsmen. Accordingly, female sportsmen's self-esteem levels decreases, and when compared with males, it can be said that they show a similar self-esteem level [5]. This also supports our study.

A significant difference was found in the self-esteem levels of female sportsmen and visually handicapped male non-sports performers $(P<0,05)$. Self-esteem has an important place in the field of sports. It is suggested that performing sports has a positive impact on self-development and high self-esteem provides to be successful in performing sports [4]. Self-esteem is directly proportional with performing sports and sports, without considering gender difference, has a positive benefit in self-development. This also supports our study.

No significant difference was found in the self-esteem levels between visually handicapped male non-sports performers and female non-sports performers ( $P>0,05)$. In a study by İnanç (1997), no significant difference was found in self-esteem levels between female and male students. In another study by Maşrabacı (1994), where the relation between self-esteem and gender difference was evaluated, it was determined that gender has no effect on self-esteem [10]. Similarly, this also supports our findings.

A significant difference was found in the self-esteem levels between male sportsmen and visually handicapped female non-sports performers $(P<0,05)$. In having a different self-esteem level of male sportsmen from the female non-sports performers, it is thought that sports provides a positive benefit. In this study, it is thought that sports effects and develops self-esteem positively.

No significant difference was found in the self-esteem levels of visually handicapped individuals who play individually or in team sports $(P>0,05)$. In a study by Aktop and Erman in 2002, no significant difference was found in the self-esteem levels of sportsmen who play individually or in team sports [4]. This also supports our study. It is thought that sports positively effects self-esteem.

As a result, sports is a necessity for a healthy and happy life and is important for all humans. But sports has a different importance for handicapped individuals, because it can open up a new window for them, who have already met a lot of obstacles in their lives and have to live with the pressure that the obstacles have caused. Without considering the level of disability type, moving, training, joining sportive activities give pleasure to individuals, and the pleasure that moving gives decreases the individual's life motivation. And this shows that it decreases the self-esteem level of the handicapped individual. Visually handicapped individual can share his loneliness with other people by doing sports, he can make friendships, can learn solidarity, He can catch an opportunity in developing his own abilities and can develop positive feelings for his own body and other people. All these can give a chance of meaningful and fulfilled life to the individual. The handicapped individuals can even get to know the educational progress of specially organized competitive sports, they can join the competitions and can taste both success and failure. So in this sense, they recognize themselves as sportsmen rather than handicapped individuals. With this selfreliance, they can learn to overcome obstacles, and with this reason their self-esteem decreases. Thus, it can be said that physical education and sportive activities contribute to physical development, self-esteem, self-reliance and sufficiency in visually handicapped individuals. We believe that sports is directly proportionalwithself-esteem[3].

\section{References:}


1. Gün E.; Self-Esteem Among Teenagers who do and do not perform Sports, Çukurova University, Institute of Health Sciences Department of Physical Education and Sports, Published Master's Thesis, Adana; p.65, 2006.

2. Aşçı F. H.; Concept of Individualism and Sports; 2. Course in Psychology of Sports; Bağırgan Press; Ankara; 7-28,1997.

3. Korkmaz M.; A Study in Self-Esteem Scale's Reliance and Validity for Adults Sample; Ege University Institute of Social Sciences; Unpublished Master's Thesis; Izmir, 1996.

4. Yörükoğlu A: Youth Age, Ankara, Tisa Press, 1985.

5. íkizler C, Karagözoğlu C. Psychology of Success in Sports. İstanbul: Alfa Press, Broadcast distribution,185 s,1997.

6. Yüksekkaya, S., Investigation of Self-Esteem amongUniversity Students From A Point of Various Variants, Ege University, Institute of Health Sciences, Master's Thesis, İzmir, 1995.

7. Willis J.D., Campbell L.F.;Exercise Psychology; Human Kinetics Publisher, 75-77;1992.

8. Dalbudak i.; Investigation of Level of Stress and Agression in Visually Handicapped Individuals who do and do not Perform Sports Between the ages of 13-15, Ege University Institute of Health Sciences, Unpublished Master's Thesis, İzmir, p.3,6,15,16,61, 2012.

9. Karademir T, Düşyılmaz E, Çoban B, Kafkas M; Self-Esteem and Emotional Intelligence in Students who Participated in Physical Education And Sports Department Special Aptitude Test, Educational Journal, Volume:18, No: 2 Kastamonu; S.653-674,2010.

10. Erşan E, Doğan O, Doğan S.: The Relation of Students in Physical Education and Coaching Department with some Socio-demographic Features, Adana, Clinical Psychology, p.36,2009.

11. Erman K, Şahan A, Can S, : Comparison of Self-Esteem Levels of Female and Male Sportsmen, Mediterranean University Department of Physical Education and Sports, Sports Journal, p.7,2004.

12. Bıyıklı L. Concept of Individualism in Physcially Handicapped Children, (From the Acceptable Level of Family), Ank. Univ. Education Units Fac. Pub. Ank.1989.

13. Öner Altıok H, Ek N, Koruklu N., Evaluation of Some Variants Related to the Self-Esteem Degree of University Students, Adnan Menderes University Faculty of Education, Educational Sciences Journal, Volume:1, Number:1 S.112, 2010. 